\title{
Activated Yeast Extract Enhances Growth, Anatomical Structure, and Productivity of Lupinus termis L. Plants under Actual Salinity Conditions
}

\author{
Ragab S. Taha ${ }^{1}$, Mahmoud F. Seleiman ${ }^{2,3, * \mathbb{D}}$, Bushra Ahmed Alhammad ${ }^{4}$, Jawaher Alkahtani ${ }^{5}$, \\ Mona S. Alwahibi ${ }^{5}$ (D) and Ayman H. A. Mahdi ${ }^{6}$ \\ 1 Botany Department, Faculty of Agriculture, Beni-Suef University, Beni Suef 62521, Egypt; \\ ragab.salama@agr.bsu.edu.eg \\ 2 Plant Production Department, College of Food and Agriculture Sciences, King Saud University, P.O. Box 2460, \\ Riyadh 11451, Saudi Arabia \\ 3 Department of Crop Sciences, Faculty of Agriculture, Menoufia University, Shibin El-kom 32514, Egypt \\ 4 Biology Department, College of Science and Humanity Studies, Prince Sattam Bin Abdulaziz University, \\ Al Kharj Box 292, Riyadh 11942, Saudi Arabia; b.alhamad@psau.edu.sa \\ 5 Department of Botany and Microbiology, College of Science, King Saud University, Riyadh 11451, \\ Saudi Arabia; Jsalqahtani@ksu.edu.sa (J.A.); malwhibi@ksu.edu.sa (M.S.A.) \\ 6 Agronomy Department, Faculty of Agriculture, Beni-Suef University, Beni Suef 62521, Egypt; \\ drayman.hamdy@agr.bsu.edu.eg \\ * Correspondence: mahmoud.seleiman@agr.menofia.edu.eg; Tel.: +96-655-315-3351
}

\section{check for}

updates

Citation: S. Taha, R.; Seleiman, M.F.; Alhammad, B.A.; Alkahtani, J.; Alwahibi, M.S.; Mahdi, A.H.A. Activated Yeast Extract Enhances Growth, Anatomical Structure, and Productivity of Lupinus termis L. Plants under Actual Salinity Conditions. Agronomy 2021, 11, 74. https:/ /doi.org/10.3390/agronomy 11010074

Received: 28 November 2020 Accepted: 28 December 2020 Published: 31 December 2020

Publisher's Note: MDPI stays neutral with regard to jurisdictional clai$\mathrm{ms}$ in published maps and institutional affiliations.

Copyright: $@ 2020$ by the authors. Licensee MDPI, Basel, Switzerland. This article is an open access article distributed under the terms and conditions of the Creative Commons Attribution (CC BY) license (https:// creativecommons.org/licenses/by/ $4.0 /)$.
Abstract: Salinity is one of the most severe environmental stresses that negatively limits anatomical structure, growth and the physiological and productivity traits of field crops. The productivity of lupine plants is severely restricted by abiotic stress, particularly, salinity in arid and semiarid regions. Activated yeast extract (AYE) can perform a vital role in the tolerance of environmental stress, as it contains phytohormones and amino acids. Thus, field experiments were conducted to explore the potential function of active yeast extract $\left(0,50,75\right.$, and $\left.100 \mathrm{~mL} \mathrm{AYE} \mathrm{L}^{-1}\right)$ in mitigating the harmful impacts of salinity stress (EC $=7.65 \mathrm{dS} \mathrm{m}^{-1}$ ) on anatomical structure, growth, and the physiological and productivity traits of two lupine cultivars: Giza 1 and Giza 2. The different AYE treatments resulted in a substantial improvement in studied attributes, for example the growth, anatomical, physiological characteristics, and seed yields of treated lupine cultivars compared with untreated plants. Among the AYE doses, $75 \mathrm{~mL} \mathrm{~L}^{-1}$ significantly improved plant growth, leaf photosynthetic pigments, total soluble sugars, total protein, and seed yields, and exposed the best anatomical attributes of the two lupine cultivars grown under saline stress. The exogenous application of $75 \mathrm{~mL}$ AYE L ${ }^{-1}$ was the most influential, and it surpassed the control results by $45.9 \%$ for 100 -seed weight and $26.9 \%$ for seed yield per hectare. On the other hand, at a concentration of $75 \mathrm{~mL} \mathrm{~L}^{-1}$ AYE there was a decrease in the alkaloids and endogenous proline under the studied salinity stress conditions. Promoted salinity stress tolerance through sufficient AYE dose is a hopeful strategy to enhance the tolerance and improve productivity of lupine into salinity stress. Furthermore, the response of lupine to salinity stress appears to rely on AYE dose. The results proved that Giza 2 was more responsive to AYE than Giza 1, showing a better growth and higher yield, and reflecting further salinity tolerance than the Giza 1 cultivar.

Keywords: lupine; actual salinity conditions; anatomy; yield; yeast extract

\section{Introduction}

During their lifetime, plants are exposed to different environmental stresses, particularly abiotic stresses, such as high salinity, heat stress, drought, and toxic heavy metals [1-9]. Salinity is one of the most primary limiting factors that can harmfully affect anatomical structure, growth, physiological traits, and productivity of crops [9-11]. Salinity stress can 
cause significant reductions in growth, chlorophyll deterioration, water status imbalance, change in stomatal movement, and ion disequilibria [12-14]. It promotes responses in plants to produce reactive oxygen species (ROS), such as $\mathrm{OH} \cdot \mathrm{H}_{2} \mathrm{O}_{2}$, and $\mathrm{O}_{2} \cdot[10,15,16]$. These ROS can cause significant harm to lipid membranes, proteins, and DNA, and they can interact with different macromolecules. However, plants cope with these types of oxidants by developing different defense mechanisms, such as antioxidant enzymes and molecules that scavenge activated oxygen that is potentially cytotoxic [17-19].

Legumes are mostly considered moderately tolerant for salt tress [20]. In Egypt, there is a focus currently on the utilization of some crops, comprising lupine (Lupinus termis L.) in newly-reclaimed agricultural lands, nevertheless most of those agricultural lands are stressed with salinity. Lupine is an important legume field crop grown for food, feed and bioenergy consumption [21], however it is sensitive to high levels of salinity, which cause substantial losses in seed. The cultivated area and seed production of lupinus during 2018 were 0.98 million (M) ha and 1,19 Mt, respectively [22]. Several studies have been conducted to investigate ways of lessening the negative salt stress effects on lupines [11,23], but most of these investigations have not identified solutions that are viable enough. Hence, there is a crucial need to investigate uncostly treatments and environmentally-friendly approaches for avoiding salinity stress and promoting the productivity of lupines.

Yeast extracts are considered a primary source of different essential amino acids, vitamins, and phytohormones $[24,25]$. Active yeast extracts (AYE) have been found to reduce drought stress on pea plants (Pisum sativum L.) and promote their growth and increased yield [26]). Furthermore, they were found to enhance the growth and improve the chlorophyll and yield of maize (Zea mays L.), bean (Phaseolus vulgaris L.), and sugar beet (Beta vulgaris L.) [27]. Consequently, yeast can perform as a vital role in the tolerance of environmental stress, as it contains phytohormones and amino acids that can enhance growth and chlorophyll in plants. Moreover, yeast has been reported to stimulate cell division and expansion, formation of chlorophyll, protein, and nucleic acid synthesis [28-30].

Recently, there has been an increasing demand for organic agricultural products that are safe for humans and livestock, and economically viable. Thus, we applied a yeast extract as a source for minerals, vitamins, and growth regulators, which included cytokines, gibberellin, and auxins, to promote growth and enhance chlorophyll efficiency, enhancing plant resistance to environmental stresses. The aims of this investigation were to study the prompting of yeast extracts $\left(0,50,75\right.$, and $\left.100 \mathrm{~mL} \mathrm{AYE} \mathrm{L}^{-1}\right)$ as bio-fertilizer to improve the anatomical structure, growth, and productivity of lupines (cv. Giza 1 and Giza 2) grown in salty soil (electrical conductivity $(\mathrm{EC})=7.65 \mathrm{dS} \mathrm{m}^{-1}$ ).

\section{Materials and Methods}

\subsection{Experimental Design, Treatments, and Growth Conditions}

Two field experiments were carried out during the 2017/2018 and 2018/2019 growing seasons at the Experimental Farm, Agriculture Faculty, Fayoum University, Egypt $\left(29^{\circ} 17^{\prime} \mathrm{N}\right.$; $30^{\circ} 53^{\prime} \mathrm{E}$ ), to examine the influence of yeast extracts ( 0 as control, 50,75 , and $100 \mathrm{~mL} \mathrm{AYE} \mathrm{L}^{-1}$ ) on the anatomical structure, growth, physiological, and productivity characteristics of two cultivars of lupine (cv. Giza 1 and Giza 2) grown in salty soil $\left(\mathrm{EC}=7.65 \mathrm{dS} \mathrm{m} \mathrm{m}^{-1}\right)$. The lupine plants were sprayed with only tap water for the control and 50, 75, and $100 \mathrm{~mL} \mathrm{~L}^{-1}$ of AYE at 20, 35, and 55 days after sowing (DAS). The treatments were determined based on a preliminary trial.

The dry yeast was activated using nutritional media, which included glucose and casein as a suitable source of $C$ and $N$ at a ratio of 6:1 and other necessary elements, such as $\mathrm{K}, \mathrm{P}, \mathrm{Fe}, \mathrm{Mn}$, and $\mathrm{Mg}$ and the incubation temperature was set according to Barnett et al. [24]. The yeast cells were grown under suitable aerobic and nutritional conditions to encourage vegetative production of the yeast and the formation of beneficial bio components, such as amino acids, carbohydrates, phytohormones (auxins, cytokines), vitamins, fatty acids, protein, enzymes, and minerals. The constituents of the AYEs are described in Table 1. The AYE was prepared once for both seasons, then it was divided into two parts. First part 
was used in the first seasons, while second part was kept in a deep freezer for the second season.

Table 1. Constituents of prepared yeast stock solution.

\begin{tabular}{cccc}
\hline Macro-Elements (\%) & Value & Micro-Elements (\%) & Value \\
\hline $\mathrm{N}$ & 1.00 & $\mathrm{Fe}$ & 0.11 \\
$\mathrm{P}$ & 0.11 & $\mathrm{Mn}$ & 0.06 \\
$\mathrm{~K}$ & 0.3 & $\mathrm{Zn}$ & 0.05 \\
$\mathrm{Mg}$ & 0.011 & $\mathrm{Cu}$ & 0.03 \\
$\mathrm{Ca}$ & 0.02 & $\mathrm{~B}$ & 0.014 \\
$\mathrm{Na}$ & 0.009 & $\mathrm{Mo}$ & 0.0002 \\
\hline Total protein $(\%)$ & 5.00 & Phyto-hormones $\left(\mathrm{mg} \mathrm{mL}^{-1}\right)$ \\
Total carbohydrate (\%) & 4.5 & Indole-3-acetic acid & 0.6 \\
& \multicolumn{3}{c}{ Gibberellins } \\
\hline
\end{tabular}

The experimental design in the current study was a split-plot in a randomized complete block design. The number of replications was three for each investigated treatment. The two cultivars were positioned in the main plots, while the AYE applications were located in the subplots. The experimental plot size was $20 \mathrm{~m}^{2}(4 \times 5)$, and the seeds were sown on the 15th and 18th of November 2017 and 2018, respectively. The agricultural operations, which included thinning, fertilization, and irrigation, were conducted following the recommendations of the Ministry of Egyptian Agriculture.

Soil analysis was conducted before sowing in the 2017/2018 and 2018/2019 seasons (Table 2) following the methods described in $[31,32]$. The soil was classified as salty soil based on its EC (7.55-7.75 $\left.\mathrm{dS} \mathrm{m}^{-1}\right)$.

Table 2. Physical and chemical properties of soil before the field experiments.

\begin{tabular}{lcc}
\hline & $\mathbf{2 0 1 7 / 2 0 1 8}$ & $\mathbf{2 0 1 8 / 2 0 1 9}$ \\
\hline Physical properties & & \\
Clay (\%) & 13.2 & 12.1 \\
Silt (\%) & 17.0 & 16.5 \\
Sand (\%) & 69.8 & 71.4 \\
Soil texture & Sandy loam & Sandy loam \\
\hline Chemical properties & & \\
pH $(1: 2.5)$ & 7.40 & 7.70 \\
EC $\left.(\mathrm{dS} \mathrm{m})^{-1}\right)$ & 7.55 & 7.75 \\
Organic matter $(\%)$ & 0.90 & 0.95 \\
CaCO $(\%)$ & 4.78 & 4.95 \\
Total N (\%) & 0.062 & 0.069 \\
Available P (mg kg & \\
Available K $\left(\mathrm{mg} \mathrm{kg}^{-1}\right.$ soil) & 7.56 & 8.00 \\
Available Fe $\left(\mathrm{mg} \mathrm{kg}^{-1}\right.$ soil) & 176 & 179 \\
\hline
\end{tabular}

\subsection{Measurements}

\subsubsection{Growth and Yield Attributes}

At 60 days-old, nine plants were randomly collected to measure their shoot length, number of leaves, branches per plant, and shoot fresh and dry weight. At physiological maturity (175 DAS), dry pods were collected, and the number of dry pods was counted per plant. After extraction, dry seeds were weighed to record the 100 seeds-weight and seed yield per ha. Seed yield per ha was calculated based on the experimental plot area.

\subsubsection{Anatomical Characteristics}

At 60 DAS of the second season, lupine stem samples (5th internode) were collected from different treatments of AYE and cultivars, then fixed in Formalin-Aceto-Alcohol 
(FAA), which was formed from $10 \mathrm{~mL}$ formalin, $5 \mathrm{~mL}$ glacial acetic acid, $35 \mathrm{~mL}$ distilled water, and $50 \mathrm{~mL}$ ethyl alcohol $95 \%$ for $4 \mathrm{~d}$. The fixed samples were washed in a $50 \%$ ethyl alcohol and dehydrated in a n-butyl alcohol series, and then fixed in paraffin wax at $57^{\circ} \mathrm{C}$. The different samples were cut by a rotary microtome to cross-sections with a thickness of $20 \mu$. Then, they were double stained with crystal violet-erythrosine, cleared in carbol xylene and fitted in Canada balsam. Using a microscope and micrometer eyepiece, the stem sections were analyzed and micro-photographed [33].

\subsubsection{Leaf Pigments}

About $200 \mathrm{mg}$ of fresh leaves was homogenized in $50 \mathrm{~mL}$ of acetone $(80 \% \mathrm{v} / \mathrm{v})$ to estimate carotenoids and chlorophylls $\mathrm{a}, \mathrm{b}\left(\mathrm{mg} \mathrm{g}^{-1} \mathrm{FW}\right)$. The mixture was then centrifuged for $10 \mathrm{~min}$ at $10,000 \times g$. Finally, using a spectrophotometer (UV-160A, Shimadzu, Japan), the filtrated supernatant was read at waves length of 665,649 , and $440 \mathrm{~nm}$. The photosynthetic pigments were calculated following the described method by [34].

\subsubsection{Total Soluble Sugar and Proline}

The quantity of total soluble sugars was estimated as following [35]. About $0.2 \mathrm{~g}$ of dried lupine leaves were homogenized with $5 \mathrm{~mL}$ of ethanol $(70 \%)$. Afterward, the mixture was centrifuged $x$ at $3500 \times g$ for a period of $10 \mathrm{~min}$. The supernatant (i.e., $0.1 \mathrm{~mL}$ ) was then mixed with $3 \mathrm{~mL}$ of anthrone. Then, samples were incubated in a warm water bath for $10 \mathrm{~min}$. Using a spectrophotometer at $625 \mathrm{~nm}$, total soluble sugar (TSS) of each sample was measured.

Proline leaf content was calculated as described by [36]: ten mL of sulfosalicylic (3\%) was homogenized with $0.5 \mathrm{~g}$ of dried lupine leaves. Next, the mixture was centrifuged for $10 \mathrm{~min}$ at 10,000 g. Afterward, the supernatant of each sample was mixed with $2 \mathrm{~mL}$ acidninhydrin and inserted in a test tube. After that, the tubes were incubated in a water bath for $30 \mathrm{~min}$ at $90{ }^{\circ} \mathrm{C}$, and then located in an ice bath. Finally, $5 \mathrm{~mL}$ of toluene was inserted to each sample, and samples were vortex-mixed for $30 \mathrm{~s}$. Using a spectrophotometer, the proline content was measured at a wave length of $520 \mathrm{~nm}$.

\subsubsection{Total Protein}

The protein content of lupine seed was analyzed by determining the percentage $\mathrm{N}$ using a conventional micro Kjeldahl following [37]. The percentage protein was calculated by multiplying grain nitrogen content by 6.25 .

\subsubsection{Total Alkaloid}

The total alkaloid content of dried lupine leaves was estimated following [38]. A measure of $0.5 \mathrm{mg}$ of dried lupine leaves was extracted in ethyl alcohol (90\%). The previous admixture was filtered using filter paper, concentrated, and dried. Then the sample was redissolved in diluted ethyl alcohol, and hydrochloric acid (3\%) was added. After extracting the admixture three times using separating funnels, hexane was added, and the mixture was shaken for $20 \mathrm{~min}$. The lower water layers were collected in a beaker, the $\mathrm{pH}$ was changed to 8.5 by adding ammonium hydroxide $3 \%$, and it was cooled at $10{ }^{\circ} \mathrm{C}$. The mixture was extracted three times (20 min each round) via chloroform in a separating funnel, then it was shaken for $20 \mathrm{~min}$. The lower layers were removed, while, the floating chloroform layers were poured into porcelain dishes after weighing. The dishes were then left to evaporate at room temperature until dry. The dishes were weighed again after being evaporated. The total alkaloid contents were expressed as percent alkaloid contents in the dry leaves. A part of the analysis, particularly of the dried samples, was conducted at King Saud University.

\subsection{Statistical Analysis}

Data were subjected to analysis of variance (ANOVA) using PASW statistics 21.0 (IBM Inc., Chicago, IL, USA). The homogeneity test of error variance was done as detailed in 
Gomez and Gomez [39]. A combined analysis was used for the data obtained from the two seasons of the current study as well as Duncan's range test was used for comparing the significant differences between different treatments of AYE and cultivars at $p \leq 0.05$.

\section{Results}

\subsection{Growth Characteristics}

The exogenous application of different concentrations of AYE $\left(50,75\right.$ and $\left.100 \mathrm{~mL} \mathrm{~L}^{-1}\right)$ on two cultivars of lupine (Giza 1 and Giza 2) substantially increased the examined growth attributes compared with untreated plants (Figure 1). However, the concentration of $75 \mathrm{~mL} \mathrm{~L} \mathrm{~L}^{-1}$ AYE showed the most substantial increases in shoot length (43.7\% and $\left.42.7 \%\right)$, number of leaves (54.8\% and $34.2 \%)$, number of branches $(25.1 \%$ and $50.0 \%)$, shoot fresh weight (124.0\% and $106.9 \%)$, and shoot dry weight (90.9\% and $83.3 \%$ ) for Giza 1 and Giza 2 cultivars, respectively followed by $100 \mathrm{~mL} \mathrm{~L}^{-1}$ AYE in comparison to untreated plants, as well as Giza 2 showed higher increases than Giza 1.

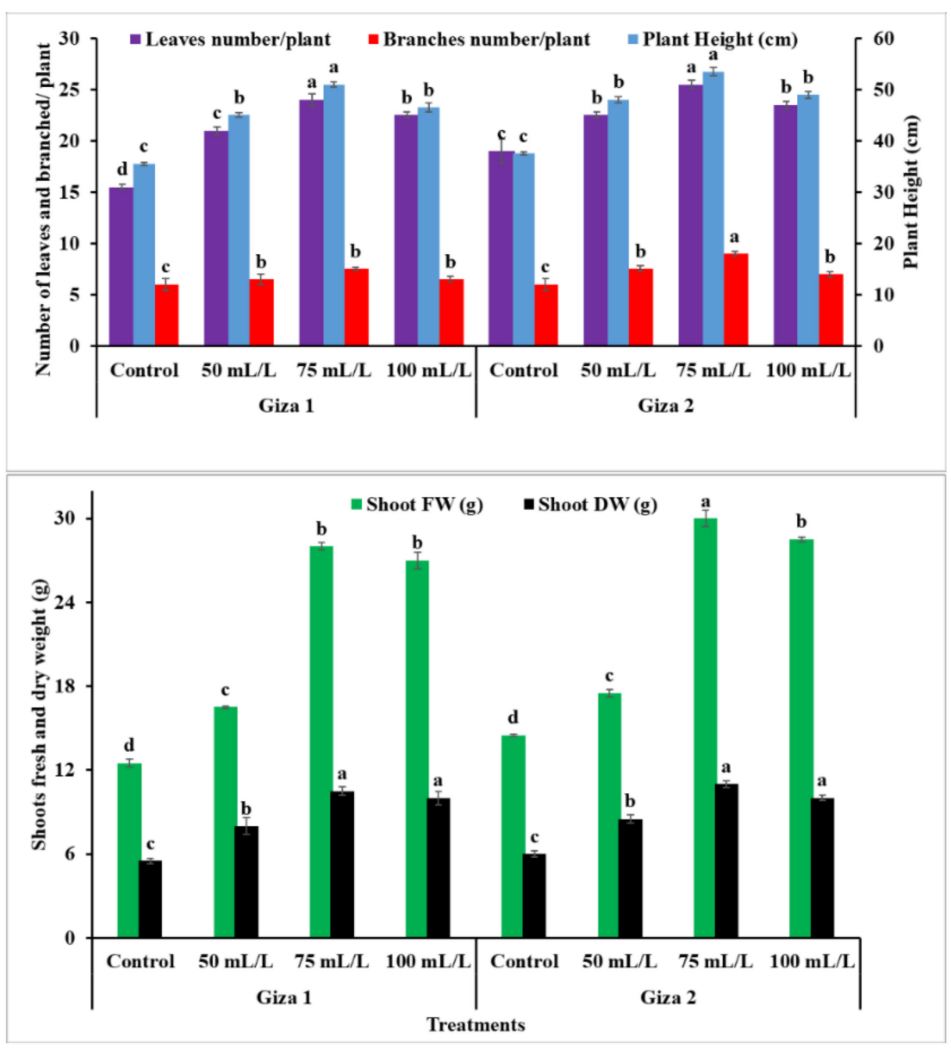

Figure 1. Effect of four active yeast extracts (AYE) exogenous applications on numbers of leaves and branches per plant and plant height (upper graph); and shoots fresh and dry weight (lower graph) of two lupine cultivars grown in reclaimed-saline soil. For each parameter, treatments followed by the same letter are not significantly differed at $p \leq 0.05$. Error bars are \pm Standard Error (SE).

\subsection{Anatomical Structure}

The readings in Table 3 and Figure 2 demonstrate that the application of different doses of AYE $\left(50,75\right.$, and $\left.100 \mathrm{~mL} \mathrm{~L}^{-1}\right)$ improved the anatomical attributes of the lupine stem. A dose of $75 \mathrm{~mL} \mathrm{~L}^{-1}$ AYE was found to be most influential, and it ameliorated the stem anatomical traits. This treatment surpassed the untreated plants by $38.41 \%$ and $29.2 \%$ for section diameter, $33.33 \%$ and $66.66 \%$ for cortex thickness, $50 \%$ and $28.57 \%$ for the number of cortical layers, $77.77 \%$ and $128.6 \%$ for the diameter of xylem vessels, $46 \%$ and $73.79 \%$ for pith diameter, and $16.9 \%$ and $14.92 \%$ for the number of pith layers of lupine cultivars Giza 1 and Giza 2, respectively. Additionally, the Giza 2 cultivar showed better anatomical traits than the Giza 1 cultivar. 
Table 3. Effect of four AYE exogenous applications on stem anatomy of two lupine cultivars grown in reclaimed-saline soil.

\begin{tabular}{|c|c|c|c|c|c|c|c|}
\hline \multicolumn{2}{|c|}{ Treatment } & \multirow{3}{*}{$\begin{array}{l}\text { Section } \\
\text { Diameter }(\mu)\end{array}$} & \multirow{3}{*}{$\begin{array}{l}\text { Cortex } \\
\text { Thickness } \\
(\mu)\end{array}$} & \multirow{3}{*}{$\begin{array}{l}\text { No. of } \\
\text { Cortical } \\
\text { Layers }\end{array}$} & \multirow{3}{*}{$\begin{array}{l}\text { Xylem } \\
\text { Vessels } \\
\text { Diameter }(\mu)\end{array}$} & \multirow{3}{*}{$\begin{array}{l}\text { Pith } \\
\text { Diameter }(\mu)\end{array}$} & \multirow{3}{*}{$\begin{array}{l}\text { No. of Pith } \\
\text { Layers }\end{array}$} \\
\hline \multirow{2}{*}{ Variety } & AYE & & & & & & \\
\hline & $\left(\mathrm{mL} \mathrm{L} \mathrm{L}^{-1}\right)$ & & & & & & \\
\hline \multirow{5}{*}{ Giza 1} & 0 & $3775.0^{\mathrm{e}}$ & $300.0^{c}$ & $6.0^{\mathrm{d}}$ & $22.5^{c}$ & $2525.0^{\mathrm{d}}$ & $32.5^{\mathrm{cd}}$ \\
\hline & 50 & $4562.5^{c}$ & $350.0^{\mathrm{b}}$ & $7.0^{\mathrm{c}}$ & $30.0^{b}$ & $2662.5^{\mathrm{d}}$ & $31.5^{\mathrm{d}}$ \\
\hline & 75 & $5225.0^{\mathrm{a}}$ & $400.0^{a}$ & $9.0^{\mathrm{a}}$ & $40.0^{\mathrm{a}}$ & $3687.5^{b}$ & $38.0^{\mathrm{a}}$ \\
\hline & 100 & $5000.0^{b}$ & $400.0^{\mathrm{a}}$ & $8.0^{b}$ & $30.0^{b}$ & $3375.0^{c}$ & $37.5^{\mathrm{a}}$ \\
\hline & Means & 4640.63 & 337.50 & 7.5 & 30.63 & 3062.50 & 34.88 \\
\hline \multirow{5}{*}{ Giza 2} & 0 & $4062.5^{\mathrm{d}}$ & $240.0^{d}$ & $7.0^{c}$ & $17.5^{\mathrm{d}}$ & $2337.5^{a}$ & $33.5^{c}$ \\
\hline & 50 & $5062.5^{b}$ & $400.0^{\mathrm{a}}$ & $8.0^{\mathrm{b}}$ & $30.0^{b}$ & $3312.5^{c}$ & $36.0^{\mathrm{b}}$ \\
\hline & 75 & $5250.0^{a}$ & $400.0^{\mathrm{a}}$ & $9.0^{\mathrm{a}}$ & $40.0^{\mathrm{a}}$ & $4062.5^{\mathrm{a}}$ & $38.5^{\mathrm{a}}$ \\
\hline & 100 & $5187.5^{a}$ & $400.0^{a}$ & $8.0^{b}$ & $40.0^{\mathrm{a}}$ & $3437.5^{c}$ & $35.0^{\mathrm{b}}$ \\
\hline & Means & 4890.63 & 360.00 & 8.00 & 31.88 & 3287.50 & 35.75 \\
\hline
\end{tabular}

For each parameter, treatments followed by the same letter are not significantly differed at $p \leq 0.05$. Error bars are \pm Standard Error (SE). $\mathrm{AYE}=$ active yeast extract.

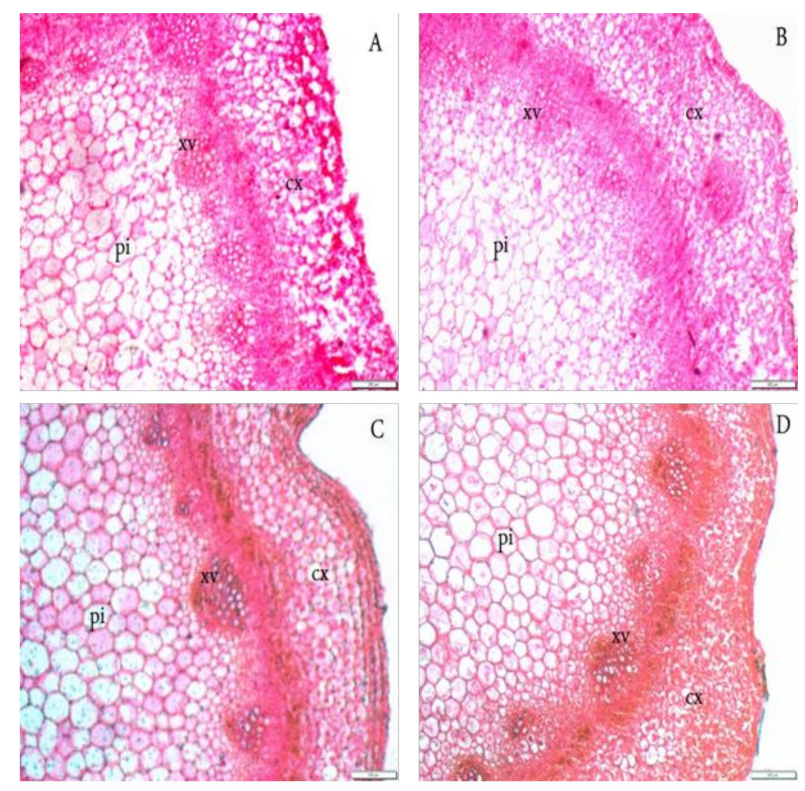

Figure 2. Effect of four AYE exogenous applications on stem anatomy of two lupine cultivars grown in reclaimed-saline soil. (A) = Control (Giza 1); (B) = Control (Giza 2); (C) = $75 \mathrm{~mL} \mathrm{AYE} \mathrm{L}{ }^{-1}$ (Giza 1); (D) = $75 \mathrm{~mL} \mathrm{AYE} \mathrm{L}^{-1}$ (Giza 2); cx = cortex; $x v=$ xylem vessel; Pi = Pith; Scale bar $=200 \mu$.

\subsection{Chlorophyll $a, b$ and Carotenoids}

The exogenous application of AYE increased the concentration of leaf pigments, i.e., chlorophylls $(\mathrm{a}, \mathrm{b})$ and carotenoids (Figure 3). The lupine plants treated with $75 \mathrm{~mL} \mathrm{~L}^{-1}$ of AYE showed the highest increases in chlorophyll a by 44.74 and $30 \%$, chlorophyll b by 46 and $32.69 \%$, and carotenoids by 45.33 and $24.72 \%$, for lupine cultivars Giza 1 and Giza 2, respectively. Additionally, Giza 2 showed significantly higher increases in chlorophylls than Giza 1, although there was no significant difference between the effect of 75 and $100 \mathrm{~mL} \mathrm{~L}^{-1}$ AYE on plants of Giza 2. 


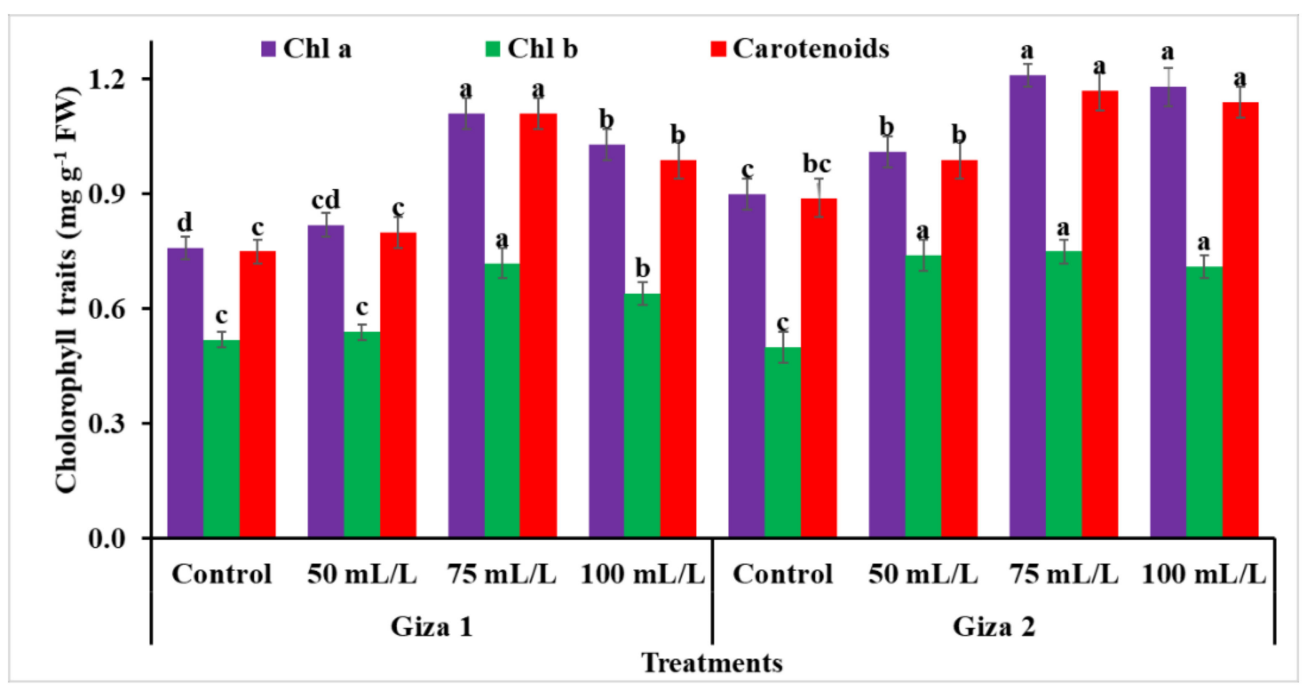

Figure 3. Effect of four AYE exogenous applications on leaf pigments of two lupine cultivars grown in reclaimed-saline soil. Chl $a=$ Chlorophyll $\mathrm{a} ; \mathrm{Chl} b=$ Chlorophyll $\mathrm{b}$. For each parameter, treatments followed by the same letter are not significantly differed at $p \leq 0.05$. Error bars are \pm Standard Error (SE).

\subsection{Total Protein, Total Soluble Sugar (TSS), Alkaloids, and Proline}

Exogenous application of AYE (i.e., 50, 75 and $100 \mathrm{~mL} \mathrm{~L}^{-1}$ AYE) on lupine plants caused a significant increment of total protein and TSS, and a significant reduction of alkaloids and proline in comparison to untreated lupine plants (Figures 4 and 5). The AYE concentration of $75 \mathrm{~mL} \mathrm{~L}^{-1}$ showed the highest increases in total protein $(54.6 \%$ and $52.7 \%)$ and TSS (49.6\% and 49.8\%) in Giza 1 and Giza 2 cultivars, respectively, but it showed reductions in alkaloids and proline by $33.3 \%$ and $50.0 \%$, and $40.7 \%$ and $45.4 \%$ in Giza 1 and Giza 2 cultivars, respectively, compared with the control plants. The application of $100 \mathrm{~mL} \mathrm{~L}^{-1}$ AYE resulted in the highest second increment after the application of $75 \mathrm{~mL} \mathrm{~L} \mathrm{~L}^{-1}$ AYE in total protein and soluble sugars. Notably, the Giza 2 cultivar showed higher increases in total protein, TSS and decreases in alkaloids and proline than the Giza 1 cultivar.

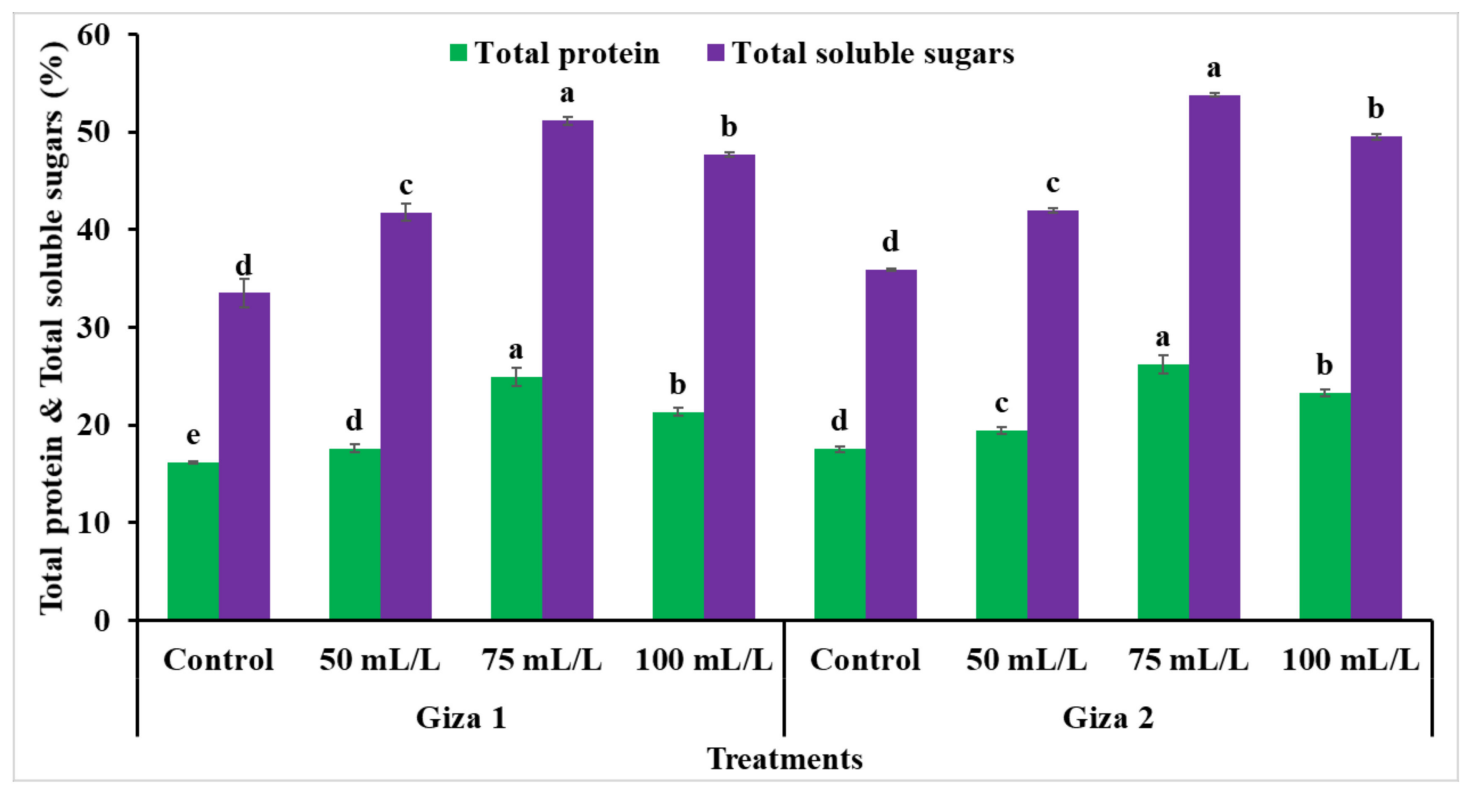

Figure 4. Effect of four AYE exogenous applications on total protein and total soluble sugars of two lupine cultivars grown in reclaimed-saline soil. For each parameter, treatments followed by the same letter are not significantly differed at $p \leq 0.05$. Error bars are \pm Standard Error (SE). 


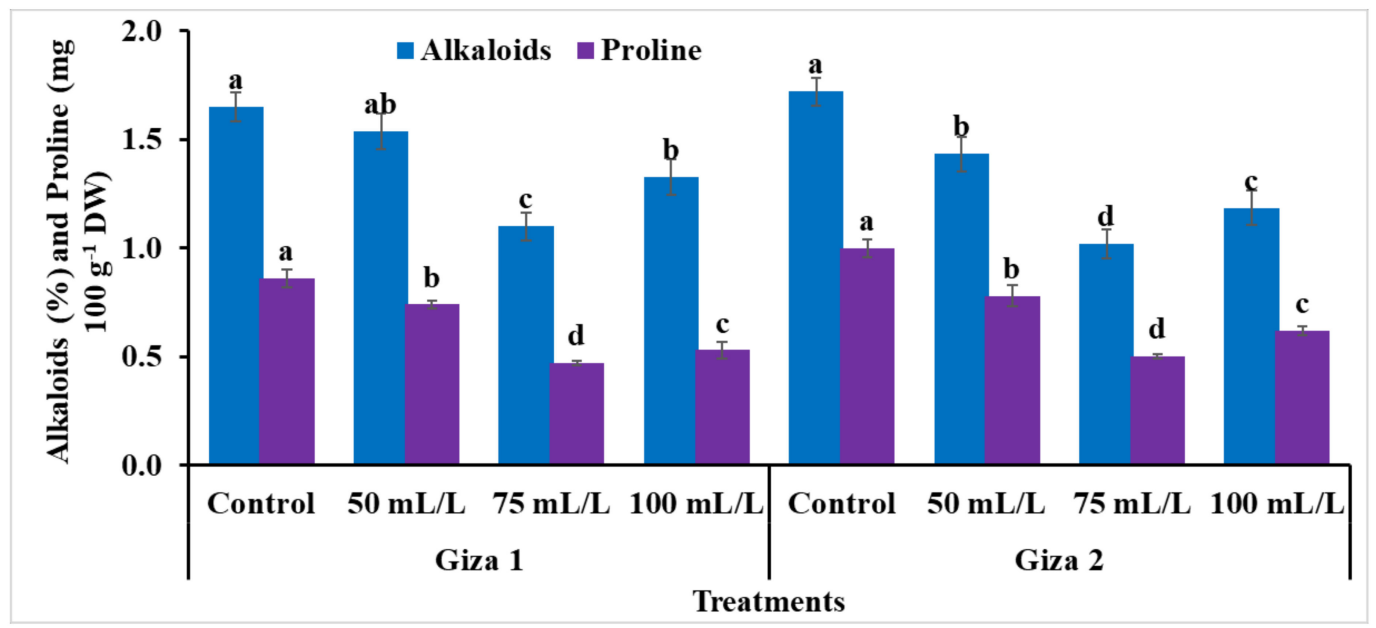

Figure 5. Effect of four AYE exogenous applications on alkaloids and proline of two lupine cultivars grown in reclaimedsaline soil. For each parameter, treatments followed by the same letter are not significantly differed at $p \leq 0.05$. Error bars are \pm Standard Error (SE).

\subsection{Yield and Its Components}

All foliar-applied AYE levels (i.e., 50, 75, and $100 \mathrm{~mL} \mathrm{~L}^{-1}$ ) significantly improved the yield of the two lupine cultivars and its components compared to those obtained from untreated lupines (Figure 6). The AYE concentration of $75 \mathrm{~mL} \mathrm{~L}^{-1}$ was the most influential followed by $100 \mathrm{~mL} \mathrm{~L}^{-1}$ AYE, and it surpassed the control results for Giza 1 and Giza 2 cultivars by $37.5 \%$ and $41.8 \%$ for dry pods per plant, $66.9 \%$ and $25.0 \%$ for average 100 -seed weight and $22.6 \%$ and $31.2 \%$ for dry seed yield per hectare, respectively. The Giza 2 cultivar showed a higher increase than the Giza 1 cultivar.

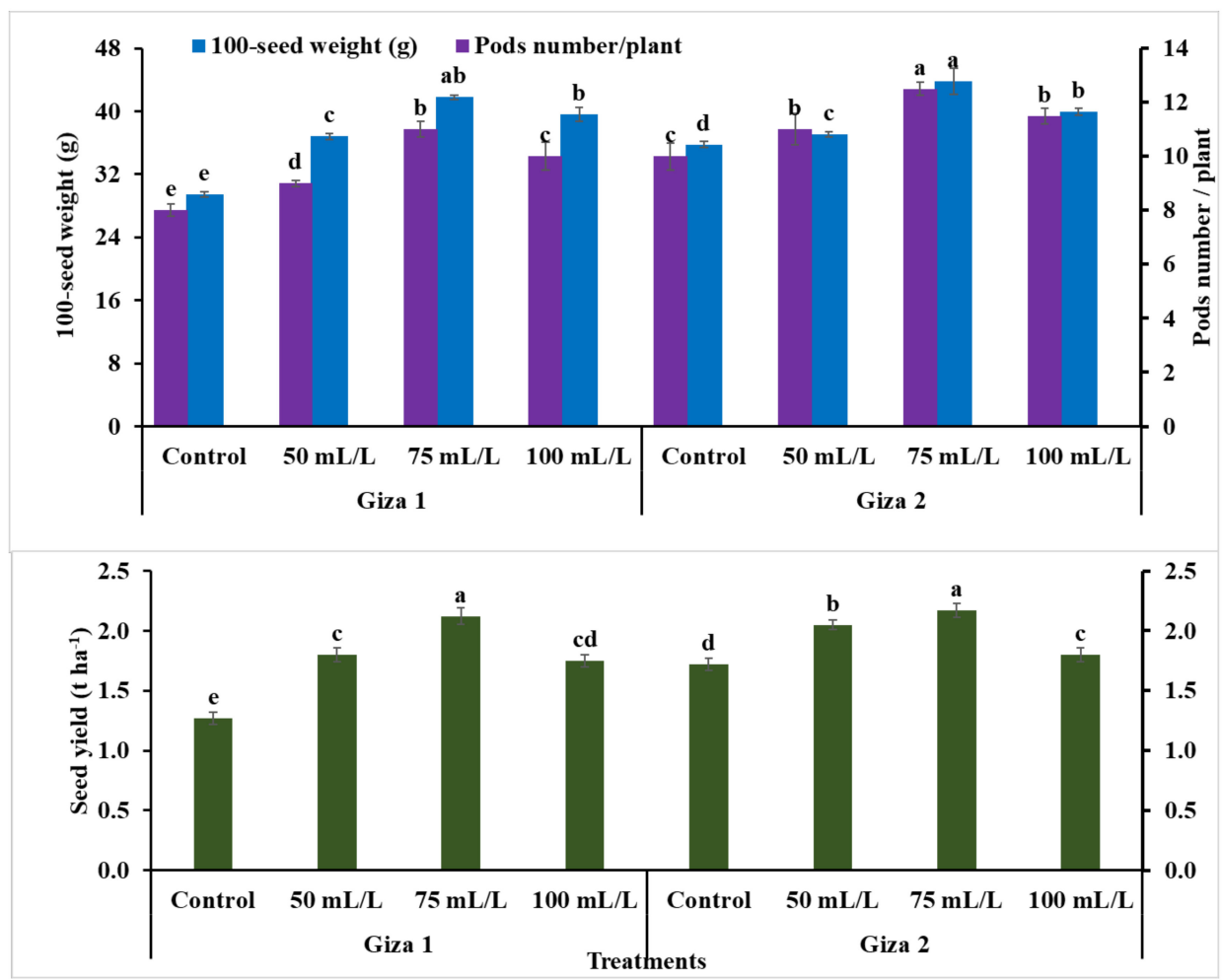

Figure 6. Effect of four AYE exogenous applications on 100-seed weight and pods number per plant (upper graph), and seed yield per ha (lower graph) of two lupine cultivars grown in reclaimed-saline soil. For each parameter, treatments followed by the same letter are not significantly differed at $p \leq 0.05$. Error bars are \pm Standard Error (SE). 


\section{Discussion}

In the current study, the harmful effect of salinity stress on the growth of lupine plants and its relationship with AYE were well investigated. Salinity stress substantially decreased the growth of lupine and this effect was alleviated by the exogenous application of AYE (Figures 1-6). Also, salinity stress is one of the abiotic stresses affecting agriculture lands worldwide $[3,9,15,16]$. Decreases in plant growth as a result of salinity stress might be endorsed to the reduction of water absorption from the soil that was caused by the hyperosmotic stress resulting from a reduction of the osmotic pressure in the soil solution [40-42]. Additionally, salinity causes increases in growth retardants, such as ABA, decreasing growth stimulators. It also causes disturbance in the water balance of plants, leading to ionic imbalance, stomatal closure, decreased photosynthesis and the subsequent suppression of growth [15].

Exogenous application of AYE into lupines significantly improved the growth characteristics of number of leaves/plant, number of branches/plant, shoot length, and shoot fresh and dry weight/plant (Figure 1), particularly $75 \mathrm{~mL} \mathrm{AYE} \mathrm{L}^{-1}$, probably due to it being a natural source of cytokines that can promote cell reproduction and differentiation or its effect on nutritious signal transduction, producing growth promoters and reducing the toxic impact of salinity [43]. It is likely that AYE improves growth of lupine since it contains different nutrients, proteins, and vitamins that have an optimistic influence on improving growth and inducing plant resistance to stress [43,44]. Additionally, the components of AYE, which contain the forerunner of indoleacetic acid, played a critical role. For example, high indole content helps to build flexibility in and induce the section of the plant cell. The highest application (i.e., $100 \mathrm{~mL} \mathrm{~L}^{-1}$ AYE) did not cause any additional beneficial enhancement than the application of $75 \mathrm{~mL} \mathrm{~L}^{-1} \mathrm{AYE}$, this can be due to the adverse effect for the highest application of AYE.

Chlorophyll is one of the most important biochemical traits that can indicate plant health status. Its level is associated with plant nutrition and water accessibility levels [10]. The advantages of the exogenous AYE application, especially $75 \mathrm{~mL} \mathrm{~L}^{-1}$, are probably due to its vital role in the enhancing plant chlorophyll content (Figure 3). The salt stress negative effects on leaf pigments were exposed in the current investigation and in other studies on different crops $[15,16,45]$. The lowest chlorophyll content in plant leaves grown under severe salt stress can be caused as a result of the thylakoid membranes degradation, with further breakdown than the chlorophyll synthesis by the proteolytic enzymes formation. For instance, the chlorophyllase enzyme is accountable for the deterioration of the chlorophyll, which is correspondingly harmful to the photosynthetic [16]. This decreases the plant photosynthetic rate and suppresses ion accumulation [46,47]. However, salt-stressed lupine plants treated with $75 \mathrm{~mL} \mathrm{~L}^{-1}$ AYE demonstrated a significant increase in photosynthetic pigments. Such increases in chlorophyll content could be because of the promotion of chlorophyll formation and suppression of its degradation. In addition, these improvements in chlorophyll concentrations were because of their produced hormones, such as indole acetic acid (IAA) and providing plants with nutrition, which promotes the growth of lupine plants and their ability to decay numerous toxic chemicals, such as ROS [47-49].

Moreover, the application of AYE significantly increased carotenoids, which could be important in stimulating salinity tolerance in stressed plants. It wes stated that the contribution of carotenoids in the photosynthetic mechanism defense against photo-inhibitory detriment through the singlet oxygen $\left({ }^{1} \mathrm{O}_{2}\right)$ is produced by the excited triplet state of chlorophyll $[17,50]$. Carotenoids can diminish the singlet oxygen species formation in a direct or indirect pathway via the neutralizing singlet oxygen as well as reducing the enthusiastic triplet state of the plant chlorophyll [51,52]. In the current study, the application of AYE to lupine plants decreased their alkaloid content (Figures 4 and 5). Proline was accumulated in large amounts in response to conditions of salt stress (control or untreated plants with AYE). This increment in proline was proposed to participate in stress tolerance in many ways. Proline can entertain as a molecular chaperon, as it is able to preserve 
the protein integrity and promote the enzyme's activity $[16,53]$. Several studies declared proline as an antioxidant, demonstrating its role as a singlet oxygen quencher as well as a ROS scavenger [54-56].

In contrast, the application of AYE reduced proline content in salt-stressed lupine plants (Figure 5). Such reduction in proline content could be attributed to the role of one or more components that are presented in AYE (i.e., amino acids, sugars, gibberellic acid and IAA; Table 1), which can compensate for the lack of proline content in plants. Amino acids and sugars can act as upregulate to the osmosis of salt-stressed lupine plants. Thus, it can protect lupine plants against the salinity stress. In the same context, the formed amount of proline in the stressed plants is related to the regulation of genes at both glutamate pathway and ornithine pathway $[57,58]$. Proline biosynthetic can be catabolized by dehydrogenase or oxidase enzymes, and converted to glutamate [59]. Moreover, gibberellic acid stimulates amylase enzyme which converts starch to glucose, therefore up-regulating cell osmosis and their protection from the damage of ROS. The exogenous yeast application can mitigate the deleterious influence of salinity stress through the proline accumulation and the defense system promotion regarding the content of phenol, ascorbic acid, and glutathione [60]. In the current study, TSSs, which are the main class of favorable solutes that have a crucial role in relieving salinity stress either by osmotic amendment or granting the plant cells resistance to desiccation [61]. The application of AYE overcomes the passive impacts of salinity stress besides cumulating TSS in cells of plant which might enhance the plant growth as demonstrated in our results (Figure 4).

Application of AYE can stimulate salt tolerance via enhancing antioxidant enzymes and safeguard photosynthetic activity besides preventing membrane peroxidation [60,62]. Furthermore, mineral element content such as N, P, K, Mn, Fe and B as well as vitamin B5 and high cytokinin can play a significant role in determining the direction and movement of metabolites from the plant leaves into the productive organs. In addition, it may play a role in the formation of protein, and nucleic acid [63], enhancing the plant defense system against oxidative damage, particularly when plants are exposed to salinity stress. As deduced in this study, salt stress reduced all the studied growth attributes. However, the application of AYE at concentrations of $75 \mathrm{~mL} \mathrm{~L}^{-1}$ improved all the measured growth traits. This finding might increment the internal structure of the stem of lupine plants grown in salty soil (Table 3 and Figure 2). All promoted traits other than growth traits (i.e., the concentration of leaf pigments, proline, TSS, and yield) through the application of AYE are associated with ameliorating the stem anatomy. This result suggests that the AYE recovers the negative influences of salinity on the stem structure. These increments in internal stem structure grant a chance for healthy movement of nutrients within cells and thus improve metabolic processes that enhance internal physiological processes resulting in vigorous growth and acceptable yield of salt-stressed lupine plants. Our results have shown that the Giza 2 cultivar had better growth rates, osmoprotectant concentrations, anatomy structure, and yield than the Giza 1 cultivar. It was concluded that Giza 2 cultivar was more salt tolerant than the Giza 1 cultivar.

In summary, the highest application of activated yeast extract $\left(100 \mathrm{~mL} \mathrm{~L}^{-1} \mathrm{AYE}\right)$ in the current study did not cause a significant enhancement for growth and productivity of lupine plants grown under salt stress compared with the application of $75 \mathrm{~mL} \mathrm{~L}^{-1}$ AYE. Therefore, the application of $75 \mathrm{~mL} \mathrm{~L}^{-1}$ AYE is considered the optimal dose for lupine plants grown under salt stress in the investigated area.

\section{Conclusions}

In summary, spraying lupine plants three times with AYE, particularly $75 \mathrm{~mL} \mathrm{~L}^{-1}$ of AYE, stimulated vegetative growth, improved the anatomical structure and increased the content of chlorophylls, carotenoids, and total soluble sugars. In contrast, the application of AYE led to a decrease in proline content and alkaloids. Therefore, exogenous application of AYE on lupine plants improved the tolerance of salinity stress through regulating antioxidants enzyme activity and osmolytes, which finally enhanced the growth and yields 
of lupines. These findings suggest that yeast extract is beneficial as a bio-fertilizer and that a dose of $75 \mathrm{~mL} \mathrm{~L}^{-1}$ of AYE is the best treatment for improving the performance of lupine plants grown in salty soil.

Author Contributions: Conceptualization, R.S.T., M.F.S., B.A.A., J.A., M.S.A., A.H.A.M.; data curation, M.F.S., B.A.A., J.A., M.S.A.; formal analysis, R.S.T., M.F.S., B.A.A., J.A., M.S.A., A.H.A.M.; investigation, M.F.S., B.A.A., J.A., M.S.A.; methodology, R.S.T., M.F.S., A.H.A.M.; resources, R.S.T., M.F.S., A.H.A.M.; software, B.A.A., J.A., M.S.A.; writing-original draft, R.S.T., M.F.S., B.A.A., J.A., M.S.A., A.H.A.M.; writing-review and editing, R.S.T., M.F.S., A.H.A.M. All authors have read and agreed to the published version of the manuscript.

Funding: The authors extend their appreciation to the Deanship of Scientific Research at King Saud University for funding this work through research group no (RG-1441-329).

Acknowledgments: The authors extend their appreciation to the Deanship of Scientific Research at King Saud University for funding this work through research group no (RG-1441-329).

Conflicts of Interest: The authors declare no conflict of interest.

\section{References}

1. Seleiman, M.F.; Santanen, A.; Stoddard, F.L.; Mäkelä, P.S.A. Feedstock Quality and Growth of Bioenergy Crops Fertilized with Sewage Sludge. Chemosphere 2012, 89, 1211-1217. [CrossRef] [PubMed]

2. Seleiman, M.F.; Santanen, A.; Kleemola, J.; Stoddard, F.L.; Mäkelä, P.S.A. Improved Sustainability of Feedstock Production with Sludge and Interacting Mychorriza. Chemosphere 2013, 91, 1236-1242. [CrossRef] [PubMed]

3. Seleiman, M.F.; Kheir, A.M.S. Maize Productivity, Heavy Metals Uptake and Their Availability in Contaminated Clay and Sandy Alkaline Soils as Affected by Inorganic and Organic Amendments. Chemosphere 2018, 204, 514-522. [CrossRef] [PubMed]

4. Seleiman, M.F.; Kheir, A.M.S. Saline Soil Properties, Quality and Productivity of Wheat Grown with Bagasse Ash and Thiourea in Different Climatic Zones. Chemosphere 2018, 193, 538-546. [CrossRef]

5. Seleiman, M.F. Use of Plant Nutrients in Improving Abiotic Stress Tolerance in Wheat. In Wheat Production in Changing Environments: Management, Adaptation and Tolerance; Hasanuzzaman, M., Nahar, K., Hossain, A., Eds.; Springer Nature: Singapore, 2019; pp. 481-495. ISBN 978-981-13-6883-7.

6. Seleiman, M.F.; Kheir, A.M.S.; Al-Dhumri, S.; Alghamdi, A.G.; Omar, E.-S.H.; Aboelsoud, H.M.; Abdella, K.A.; Abou El Hassan, W.H. 2019. Exploring optimal tillage improved soil characteristics and productivity of wheat irrigated with different water qualities. Agronomy 2019, 9, 233. [CrossRef]

7. Seleiman, M.F.; Alotaibi, M.A.; Alhammad, B.A.; Alharbi, B.M.; Refay, Y.; Badawy, S.A. Effects of ZnO Nanoparticles and Biochar of Rice Straw and Cow Manure on Characteristics of Contaminated Soil and Sunflower Productivity, Oil Quality, and Heavy Metals Uptake. Agronomy 2020, 10, 790. [CrossRef]

8. Seleiman, M.F.; Santanen, A.; Mäkelä, P.S.A. Recycling Sludge on Cropland as Fertilizer-Advantages and Risks. Resour. Conserv. Recycl. 2020, 155, 104647. [CrossRef]

9. Taha, R.; Seleiman, M.F.; Alotaibi, M.; Alhammad, B.A.; Rady, M.M.; Mahdi, A.H.A. Exogenous Potassium Treatments Elevate Salt Tolerance and Performances of Glycine max L. by Boosting Antioxidant Defense System Under Actual Saline Field Conditions. Agronomy 2020, 10, 1741. [CrossRef]

10. Dawood, M.G.; Taie, H.A.A.; Nassar, R.M.A.; Abdelhamid, M.T.; Schmidhalter, U. The Changes Induced in the Physiological, Biochemical and Anatomical Characteristics of Vicia Faba by The Exogenous Application of Proline Under Seawater Stress. S. Afr. J. Bot. 2014, 93, 54-63. [CrossRef]

11. Rady, M.M.; Taha, R.S.; Mahdi, A.H.A. Proline Enhances Growth, Productivity and Anatomy of Two Cultivars of Lupinus termis L. Grown Under Salt Stress. S. Afr. J. Bot. 2016, 102, 221-227. [CrossRef]

12. Al-Ashkar, I.; Alderfasi, A.; El-Hendawy, S.; Al-Suhaibani, N.; El-Kafafi, S.; Seleiman, M.F. Detecting Salt Tolerance in Doubled Haploid Wheat Lines. Agronomy 2019, 9, 211. [CrossRef]

13. Al-Ashkar, I.; Alderfasi, A.; Ben Romdhane, W.; Seleiman, M.F.; El-Said, R.A.; Al-Doss, A. Morphological and Genetic Diversity within Salt Tolerance Detection in Eighteen Wheat Genotypes. Plants 2020, 9, 287. [CrossRef] [PubMed]

14. Ding, Z.; Kheir, A.S.; Ali, O.A.; Hafez, E.; Elshamey, E.A.; Zhou, Z.; Wang, B.; Lin, X.; Ge, Y.; Fahmy, A.E.; et al. A vermicompost and deep tillage system to improve saline-sodic soil quality and wheat productivity. J. Environ. Manag. 2020, 277, 111388. [CrossRef] [PubMed]

15. Taha, R.S. Improving Salt Tolerance of Helianthus annuus, (L.) Plants by Moringa oleifera Leaf Extract. Egypt. J. Agron. 2016, 38, 117-140.

16. Rady, M.M.; Taha, R.S.; Semida, W.M.; Alharby, H.F. Modulation of Salt Stress Effects on Vicia faba L. Plants Grown on a Reclaimed-Saline Soil by Salicylic Acid Application. Rom. Agric. Res. 2017, 34, 175-185.

17. Elansary, H.O.; Szopa, A.; Kubica, P.; Ekiert, H.; Ali, H.M.; Elshikh, M.S.; Abdel-Salam, E.M.; El-Esawi, M.; El-Ansary, D.O. Bioactivities of Traditional Medicinal Plants in Alexandria. Evid. Based Complement. Altern. Med. 2018, 2018, 1463579. [CrossRef] 
18. Al Mahmud, J.; Bhuyan, M.B.; Anee, T.I.; Nahar, K.; Fujita, M.; Hasanuzzaman, M. Reactive Oxygen Species Metabolism and Antioxidant Defense in Plants Under Metal/Metalloid Stress. In Plant Abiotic Stress Tolerance; Hasanuzzaman, M., Hakeem, K., Nahar, K., Alharby, H., Eds.; Springer: Cham, Switzerland, 2019; pp. 221-257.

19. Abdelaal, K.A.; El-Maghraby, L.M.; Elansary, H.; Hafez, Y.M.; Ibrahim, E.I.; El-Banna, M.; El-Esawi, M.; Elkelish, A. Treatment of Sweet Pepper with Stress Tolerance-Inducing Compounds Alleviates Salinity Stress Oxidative Damage by Mediating the Physio-Biochemical Activities and Antioxidant Systems. Agronomy 2020, 10, 26. [CrossRef]

20. Subbarao, G.V.; Johansen, C.J. Potential for genetic improvement in salinity tolerance in legumes. In Handbook of Plant and Crop Stress; Pessarakli, M., Ed.; Marcel Dekker: New York, NY, USA, 1993; pp. 581-591.

21. Seleiman, M.F.; Santanen, A.; Stoddard, F.L.; Mäkelä, P. Maize and white lupin as bioenergy crops grown in soil amended with sewage sludge. In Proceedings of the 'Agro2010, the XIth ESA Congress', Montpellier, France, 29 August-3 September 2010; Wery, J., Shili-Touzi, I., Perrin, A., Eds.; Agropolis International Editions: Montpellier, France; pp. 207-208.

22. FAOSTAT_Food and Agriculture Organization of the United Nations Statistics Division. 2020. Available online: http:/ / faostat. fao.org/site/567/DesktopDefault.aspx (accessed on 20 November 2020).

23. Akladious, S.A.; Hanafy, R.S. lleviation of oxidative effects of salt stress in white lupine, (Lupinus termis L.) plants by foliar treatment with L-arginine. J. Anim. Plant. Sci. 2018, 28, 165-176.

24. Barnett, J.A.; Payne, R.W.; Yarrow, D. Yeasts: Characteristics and Identification, 3rd ed.; Cambridge University Press: Cambridge, UK, 1990.

25. Abdelaal, K.A.; Hafez, Y.M.; El Sabagh, A.; Saneoka, H. Ameliorative Effects of Abscisic Acid and Yeast on Morpho-Physiological and Yield Characteristics of Maize Plant, (Zea mays L.) Under Water Deficit Conditions. Fresen. Environ. Bull. 2017, 26, 7372-7383.

26. Xi, Q.; Lai, W.; Cui, Y.; Wu, H.; Zhao, T. Effect of Yeast Extract on Seedling Growth Promotion and Soil Improvement in Afforestation in a Semiarid Chestnut Soil Area. Forests 2019, 10, 76. [CrossRef]

27. Kasim, W.A.E.A.; AboKassem, E.M.; Ragab, G.A.A. Ameliorative Effect of Yeast Extract, IAA and Green-Synthesized Nano Zinc Oxide on the Growth of Cu-Stressed Vicia faba Seedlings. Egypt. J. Bot. 2017, 57, 1-10. [CrossRef]

28. El-Desouky, S.A.; Wanas, A.L.A.; Khedr, Z.M.A. Utilization of Some Natural Plant Extracts, (Garlic and Yeast) as Seed-Soaked Materials to Squash, (Cucurbita pepo, L.). Effect on Growth, Sex Expression and Fruit Yield and Quality. Ann. Agric. Sci. Moshtohor 1998, 36, 839-854.

29. Wanas, A.L. Resonance of Faba Bean, (Vicia faba L.) Plants to Seed Soaking Application with Natural Yeast and Carrot Extracts. Ann. Agric. Sci. Moshtohor 2002, 40, 259-278.

30. Wanas, A.L. Trails for Improving Growth and Productivity of Tomato Plants Grown in Winter. Ann. Agric. Sci. Moshtohor 2006, 44, 466-471.

31. Klute, A. Methods of Soil Analysis: Part. 1—Physical and Mineralogical Methods, 2nd ed.; American Society of Agronomy: Madison, WI, USA, 1986.

32. Page, A.I.; Miller, R.H.; Keeney, D.R. Methods of Soil Analysis: Part. 2-Chemical and Microbiological Properties, 2nd ed.; American Society of Agronomy: Madison, WI, USA, 1982.

33. Nassar, M.A.; El-Sahhar, K.F. Botanical Preparations and Microscopy, (Microtechnique); Academic Bookshop: Dokki, Giza, Egypt, 1998; p. 219.

34. Lichtenthaler, H.K.; Wellburn, A.R. Determination of Total Carotenoids and Chlorophylls a and b of Leaf Extracts in Different Solvents. Biochem. Soc. Trans. 1983, 11, 591-592. [CrossRef]

35. Irigoyen, J.J.; Emerich, D.W.; Sanchez-Diaz, M. Water Stress Induced Changes in the Concentrations of Proline and Total Soluble Sugars in Nodulated Alfalfa, (Medicago sativa) Plants. Plant. Physiol. 1992, 8, 455-460. [CrossRef]

36. Bates, L.S.; Waldren, R.P.; Teare, I.D. Rapid determination of free proline for water-stress studies. Plant. Soil 1973, $39,205-207$. [CrossRef]

37. Bremner, J.M.; Mulvaney, C.S. Nitrogen-Total. Methods of Soil Analysis: Part 2-Chemical and Microbiological Properties; Page, A.L., Miller, R.H., Keeney, D.R., Eds.; American Society of Agronomy, Soil Science Society of America: Madison, WI, USA, 1992; pp. 595-624.

38. Misra, N.; Gupta, A.K. Effect of Salinity and Different Nitrogen Sources on the Activity of Antioxidant Enzymes and Indole Alkaloid Content in Catharanthus roseus Seedlings. J. Plant. Physiol. 2006, 163, 11-18. [CrossRef]

39. Gomez, K.A.; Gomez, A.A. Statistical Procedures for Agricultural Research, 2nd ed.; John Wiley \& Sons: Singapore, $1984 ;$ p. 680.

40. Farsiani, A.; Ghobadi, M.E. Effects of PEG and NaCl Stress on Two Cultivars of Corn, (Zea mays L.) at Germination and Early Seedling Stages. World Acad. Sci. Eng. Technol. 2009, 57, 382-385.

41. Wu, D.; Qiu, L.; Xu, L.; Ye, L.; Chen, M.; Sun, D.; Chen, Z.; Zhang, H.; Jin, X.; Dai, F.; et al. Genetic Variation of HvCBF Genes and Their Association with Salinity Tolerance in Tibetan Annual Wild Barley. PLoS ONE 2011, 6, e22938. [CrossRef]

42. Mansour, E.; Moustafa, E.S.A.; Desoky, E.-S.M.; Ali, M.M.A.; Yasin, M.A.T.; Attia, A.; Alsuhaibani, N.; Tahir, M.U.; El-Hendawy, S. Multidimensional Evaluation for Detecting Salt Tolerance of Bread Wheat Genotypes Under Actual Saline Field Growing Conditions. Plants 2020, 9, 1324. [CrossRef]

43. Medani, R.A.; Taha, R.S. Improving Growth and Yield of Caraway, (Carum carvi L.). Plants by Decapitation and/or Active Dry Yeast Application. Int. J. Curr. Microbiol. Appl. Sci. 2015, 4, 47-60. 
44. Sarhan, T.; Abdullah, O.K. Effect of Azotobacter Inoculation, Dry Bread Yeast Suspension and Varying Levels of Urea on Growth of Potato Cv. Desiree. In Proceedings of the World Food System-A Contribution from Europe, Tropentag, Zurich, Germany, 14-16 September 2010.

45. Semida, W.M.; Taha, R.S.; Abdelhamid, M.T.; Rady, M.M. Foliar-Applied $\alpha$-Tocopherol Enhances Salt-Tolerance in Vicia faba L. Plants Grown Under Saline Conditions. S. Afr. J. Bot. 2014, 95, 24-31. [CrossRef]

46. Jaleel, C.A.; Sankar, B.; Sriaharan, R.; Panneerselvam, R. Soil Salinity Alters Growth, Chlorophyll Content, and Secondary Metabolite Accumulation in Catharanthus roseus. Turk. J. Biol. 2008, 32, 79-83.

47. Mafakheri, A.; Siosemardeh, A.; Bahramnejad, B.; Struik, P.C.; Sohrabi, Y. Effect of Drought Stress on Yield, Proline and Chlorophyll Contents in Three Chickpea Cultivars. Aust. J. Crop. Sci. 2009, 48, 580-585.

48. Amprayn, K.O.; Rose, M.T.; Kecskés, M.; Pereg, L.; Nguyen, H.T.; Kennedy, I.R. Plant Growth Promoting Characteristics of Soil Yeast, (Candida tropicalis HY) and Its Effectiveness for Promoting Rice Growth. Appl. Soil Ecol. 2012, 61, 295-299. [CrossRef]

49. Pérez-Montaño, F.; Alías-Villegas, C.; Bellogín, R.A.; Del Cerro, P.; Espuny, M.R.; Jiménez-Guerrero, I.; López-Baena, F.J.; Ollero, F.J.; Cubo, T. Plant Growth Promotion in Cereal and Leguminous Agricultural Important Plants: From Microorganism Capacities to Crop Production. Microbiol. Res. 2014, 169, 325-336. [CrossRef]

50. Gill, S.S.; Tuteja, N. Reactive Oxygen Species and Antioxidant Machinery in Abiotic Stress Tolerance in Crop Plants. Plant. Physiol. Biochem. 2010, 48, 909-930. [CrossRef]

51. Foyer, C.H.; Harbinson, J.; Mullineaux, P. Oxygen Metabolism and the Regulation of Photosynthetic Electron Transport. In Causes of Photooxidative Stress and Amelioration of Defense Systems in Plants; CRC Press: New York, NY, USA, 1994; pp. 1-42.

52. Le Mire, G.; Nguyen, M.L.; Fassotte, B.; Du Jardin, P.; Verheggen, F.; Delaplace, P.; Jijakli, M.H. Implementing Plant Biostimulants and Biocontrol Strategies in the Agroecological Management of Cultivated Ecosystems. A Review. Biotechnol. Agron. Soc. Environ. 2016, 20, 299-313.

53. Rajendrakumar, C.S.V.; Suryanarayana, T.; Reddy, A.R. DNA Helix Destabilization by Proline and Betaine: Possible Role in the Salinity Tolerance Process. FEBS Lett. 1997, 410, 201-205. [CrossRef]

54. Smirnoff, N.C.; Cumbes, Q.J. Hydroxyl Radical Scavenging Activity of Compatible Solutes. Phytochemistry 1989, 28, 1057-1060. [CrossRef]

55. Bulgari, R.; Franzoni, G.; Ferrante, A. Biostimulants Application in Horticultural Crops Under Abiotic Stress Conditions. Agronomy 2019, 9, 306. [CrossRef]

56. Sofy, M.R.; Seleiman, M.F.; Alhammad, B.A.; Alharbi, B.M.; Mohamed, H.I. Minimizing Adverse Effects of Pb on Maize Plants by Combined Treatment with Jasmonic, Salicylic Acids and Proline. Agronomy 2020, 10, 699. [CrossRef]

57. Lei, P.; Xu, Z.; Liang, J.; Luo, X.; Zhang, Y.; Feng, X.; Xu, H. Poly, (g-glutamic acid) enhanced tolerance to salt stress by promoting proline accumulation in Brassica napus L. Plant. Growth Regul. 2016, 78, 233-241. [CrossRef]

58. Mansour, M.M.F.; Ali, E.F. Evaluation of proline functions in saline conditions. Phytochemistry 2017, 140, 52-68. [CrossRef] [PubMed]

59. Sekhar, P.N.; Amrutha, R.N.; Sangam, S.; Verma, D.P.; Kishor, P.B. Biochemical characterization, homology modeling and docking studies of ornithine deltaaminotransferase-An important enzyme in proline biosynthesis of plants. J. Mol. Graph. Model. 2007, 26, 709-719. [CrossRef]

60. Emam, M.M. Efficiency of Yeast in Enhancement of the Oxidative Defense System in Salt-Stressed Flax Seedlings. Acta Biol. Hung. 2013, 64, 118-130. [CrossRef]

61. Hassanein, R.A.; Bassuony, F.M.; Baraka, D.M.; Khalil, R.R. Physiological Effects of Nicotinamide and Ascorbic Acid on Zea mays Plant Grown Under Salinity Stress. 1-Changes in Growth, Some Relevant Metabolic Activities and Oxidative Defense Systems. Res. J. Agric. Biol. Sci. 2009, 5, 72-81.

62. Van Oosten, M.J.; Pepe, O.; De Pascale, S.; Silletti, S.; Maggio, A. The Role of Biostimulants and Bioe Ectors as Alleviators of Abiotic Stress in Crop Plants. Chem. Biol. Technol. Agric. 2017, 41, 5. [CrossRef]

63. Sarhan, T.Z.; Ali, S.T.; Rasheed, S.M.S. Effect of Bread Yeast Application and Seaweed Extract on Cucumber, (Cucumis sativus L.) Plant Growth, Yield and Fruit Quality. Mesopotamia J. Agric. 2011, 39, 26-34. [CrossRef] 